\title{
REVIEW JURNAL PROMOSI MELALUI
}

\section{MEDIA SOSIAL}

\author{
RION (C1B1 17 219), LA ODE SAMBA (C1B1 17 159),
}

MUH. DACHRIANSYAH (C1B1 17 185), RIZAL (C1B1 17 222).

Program Studi Ilmu Pemerintahan

Universitas Halu Oleo

\section{Promosi Kuliner Jepang Melalui Media Sosial Sebagai Bentuk} Diplomasi Publik : Studi Facebook Kedutaan Besar Jepang di Indonesia

Permasalahan yang di angkat dalam jurnal ini adalah Bagaimana Kedutaan Besar Jepang mempromosikan Kuliner Jepang di Indonesia Melalui Media Sosial Facebook Sebagai Bentuk Diplomasi Publik. Seiring dengan perkembangan teknologi dan informasi pada zaman ini. Dampak globalisasi menghadirkan bentuk dan jenis diplomasi baru atau diplomasi multijalur yang dilakukan oleh aktor pemerintah maupun non-pemerintah. (Djelantik, 2008).salah satunya adalah Diplomasi Publik untuk mempromosikan budaya Pemerintah Jepang dengan mengembangkan dan melaksanakan berbagai kegiatan diplomasi melalui media sosial di Indonesia sebagai upaya untuk memperkuat hubungan jangka panjang bagi kedua negara.

Penelitian ini bertujuan untuk membahas mengenai bagaimana promosi kuliner Kedutaan Besar Jepang di Indonesia melalui media sosial Facebook sebagai bentuk diplomasi publik di antara kedua negara, juga bagaimana Manfaat dari keberadaan media sosial telah dirasakan oleh pengguna termasuk pemerintah Jepang. Kedutaan Besar Jepang di Indonesia memilih media sosial seperti 
Facebook dan Istagram sebagai alat promosi dan sarana informasi untuk menarik minat dan perhatian publik di Indonesia

Metode penelitian : Dalam jurnal ini Penelitian yang di gunakan bersifat deskriptif kualitatif dengan subjek penelitian ialah media sosial Facebook Kedutaan Besar Jepang di Indonesia. Sedangkan teknik pengumpulan data di lakukan melalui wawancara, dan dokumentasi. Dalam penelitian ini yang menjadi informan yaitu admin Facebook Kedutaan Besar Jepang di Indonesia dan salah satu anggota Sekretariat.

Hasil dari penelitian ini adalah Kedutaan Besar Jepang di Indonesia menggunakan media sosial seperti facebook dalam mempromosikan kuliner hal ini merupakan cara yang efektif mengingat Indonesia merupakan salah satu pengguna terbesar media sosial di dunia dalam mempromosikan Kuliner dan Diplomasi Kedutaan Besar Jepang di Indonesia Melalui Media Sosial dianggap mampu membantu negara dalam mencapai tujuannya, seperti upaya membentuk citra atau nation branding. Diplomasi melalui media sosial juga dipandang sebagai instrumen yang efektif dalam upaya menjaga reputasi suatu negara (image management) karena dianggap mampu menghadirkan komunikasi dua arah diantara penggunanya. (Bjola \& Holmes, 2015). Dalam hal penggunaan media sosial sebagai alat mendukung kegiatan diplomasi publik, media sosial seperti Facebook dan Instagram dianggap mampu menjalin hubungan dengan publik secara lebih luas.

Dalam hal penggunaan media sosial sebagai alat mendukung kegiatan diplomasi publik, media sosial seperti Facebook dan Instagram dianggap mampu menjalin hubungan dengan publik secara lebih luas. Adapun keterlibatan media sosial dengan publik dapat dilihat dari tiga hal utama, yaitu dalam hal digital agenda setting, presence expansion, dan digital conversation generating. Digital agenda-setting adalah kemampuan media sosial dalam menyebarkan informasi kepada publik yang selanjutnya menghadirkan sebuah diskusi di tingkat masyarakat luas, artinya media sosial sebagai instrument yang memberikan 
peluang serta kesempatan bagi para diplomat ketika menentukan agenda apa yang akan dibahas di platform digital.

Pada platform instagram dibuat untuk mempublikasikan kegiatan Kedutaan Besar Jepang di Indonesia informasi ini sebagai besar berupa foto-foto dan berbagai kegiatan, dan sesekali juga ditampilkan pertemuan di belakang layar dari aktivitas diplomasi.

Pada flatform Facebook selain berisi foto kegiatan media sosial ini juga berfungsi sebagai penyedia berbagai informasi yang disampaikan pada website Kedutaan Besar Jepang di Indonesia dengan konten yang lebih kreatif dan dengan format yang userfriendly serta menyediakan informasi resmi, tujuan Kedutaan Besar Jepang menyediakan akun Facebook adalah untuk menjaga dialog dengan para pengikut dan untuk menyampaikan reaksi terutama terhadap upaya penyampaian informasi palsu tentang Kedutaan Besar Jepang dan untuk menuliskannya kembali cerita yang benar. Pemerintah Jepang dalam hal ini Kedutaan Besar Jepang juga berusaha untuk menjaga hubungan yang dekat dengan Indonesia dengan mengadakan berbagai kegiatan yang berkaitan dengan hubungan bilateral.

Saran yang dapat diberikan dalam review ini yaitu selanjutnya peneliti mungkin dapat melanjutkan mengenai flatform-flatform lain penyedia informasi Kedutaan Besar Jepang di Indonesia misalnya seperti Twitter dan Youtube agar masyarakat Indonesia dapat mengenal lebih jauh tentang promosi kuliner Jepang melalui media sosial.

\section{Promosi Pariwista Melalui Digital Diplomacy: Upaya}

\section{Internasionalisasi Pariwisata Daerah}

Permasalahan yang diangkat dalam jurnal ini yaitu, Pergeseran paradigma pelayanan publik serta perkembangan Kecanggihan TIK secara signifikan terintegrasi dengan aktivitas pemerintah salah satunya diplomasi. Situasi ini kemudian menyebabkan ilmuwan politik memandang bahwa fenomena ini sebagai proses transformasi dalam diplomasi. Salah satunya diplomasi digital 
untuk itu di karenakan Masih sedikit ditemukan studi yang mengeksplor mengenai diplomasi digital sebagai instrument promosi wisata dalam level pemerintah daerah.. penulis tertarik untuk mengangkat masalah tentang implementasi fungsi teknologi informasi dan komunkasi dalam area pelayanan publik salah satunya Promosi Pariwisata Melalui Digital Diplomacy: Upaya Internasionalisasi Pariwisata Daerah.

Dalam mendukung untuk mengatasi masalah tersebut maka penelitian ini bertujuan untuk membahas tentang upaya internasionalisasi dengan mengenalkan pariwisata daerah ke tingkat internasional dengan menggunakan diplomasi digital sebagai media promosi suatu negara untuk mencapai tujuan kebijakan luar negeri.

Dalam jurnal ini penelitian yang di gunakan adalah Metode kualitatif dengan menggunakan Data primer dalam studi ini bersumber dari hasil wawancara, sedangkan data sekunder didapatkan dari website dan media sosial yang digunakan Dinas Pariwisata dan Ekonomi Kreatif pemerintah Kabupaten Wakatobi dalam mempromosikan pariwisata Wakatobi. Wawancara digunakan sebagai sumber data dengan jumlah informan sebanyak tiga orang. Informan dalam penelitian ialah pegawai pada kantor Dinas Pariwisata dan Ekonomi Kretaif Kabupaten Wakatobi, yaitu Sekretaris Dinas, Kepala Bidang Pemasaran Dinas Pariwisata dan Ekonomi Kreatif, dan Staf Pengelola situs/website yang bertanggung jawab dalam diplomasi digital. informan dalam penggunaan TIK dan berdasarkan pengalaman dan keterlibatan mereka dalam aktivitas diplomasi digital dan promosi pariwisata Wakatobi. Adapun analisis yang di gunakan adalah Analysis Interactive dari Miles dan Huberman (1994) digunakan sebagai analisis data dalam studi ini yang menggambarkan kegiatan analisis dalam beberapa tahapan pengumpulan data, reduksi data, penyajian data, dan penarikan kesimpulan atau verifikasi data.

Hasil dari penelitian ini yaitu dalam pelaksanaan promosi wisata daerah Dinas Pariwisata dan Ekonomi Kreatif Kabupaten Wakatobi berjalan lancar dan efektif dengan menggunakan media TIK seperti pemanfaatan internet. Dalam 
konteks ini diplomasi digital mempromosikan penggunaan TIK untuk memenuhi kebijakan suatu daerah sebagai upaya untuk memberikan informasi tidak hanya dalam negeri tapi juga luar negeri. Selain itu diplomasi pemerintah daerah pemerintah Wakatobi juga dilakukan dengan mengikuti berbagai acara-acara internasional seperti pameran diberbagai negara. Selain itu penggunaan media sosial juga menjadi alat bagi pemerintah daerah dalam mempromosikan pariwisata daerah Wakatobi seperti penggunaan Facebook, Instagram dan Twitter. Nama akun Facebook dan Instagram yaitu@visitwakatobi sedangkan untuk twitter dengan nama akun @tourismwakatobi. Media sosial ini dimanfaatkan oleh pemerintah daerah dan untuk memberikan informasi terkait kepariwisataan kepada wisatawan asing diberbagai belahan dunia. Meskipun demikian dalam pengelolaan website ternyata masih ditemui kendala dalam mengoperasikannya. Misalnya Beberapa kendala tersebut seperti ketersediaan sumberdaya manusia yang berkutat di industri ini masih rendah, update informasi dari Pemerintah Daerah masih mengalami kesusahan bahasa dalam menerjemahkan informasi dari bahasa indonesia ke dalam bahasa inggris itu masih sulit jaringan internet yang masih belum stabil dan belum cepat seperti yang telah digunakan oleh KabupatenKabupaten lain yang notabanenya bukan daerah kepulauan, hanya dua akses fasilitas internet yang tersedia di Pemerintah Daerah yaitu Indihome dan Kominfo. Namun terlepas dari tantangan tersebut Dinas Pariwisata dan Ekonomi Kreatif Wakatobi juga menggunakan website resmi dalam memberikan informasi mengenai pariwisata Wakatobi. Website ini menggunakan dua Bahasa yaitu Inggris dan Indonesia. Keberadaan layanan World Wide Web (WWW) memungkinkan pemerintah daerah untuk terus berinovasi dalam memanfaatkan TIK dan bekerja sama agent promosi pariwisata salah satunya adalah GENPI dikenal dengan Generasi Pesona Indonesia suatu komunitas relawan pariwisata yang memang dibentuk oleh Kementerian Pariwisata yang bertugas membantu promosi wisata lebih berbasis digital dan menjadi satu strategi pemasaran pariwisata. 
Saran yang dapat diberikan mengenai jurnal penelitian ini yaitu selanjutnya dapat di kaji lebih jauh mengenai hambatan hambatan dari diplomasi digital baik itu dalam hal mempromosikan melalui media sosial maupun melalui website. Bukan hanya hambatan hambatan tapi sebaik nya juga solusi dalam menghadapi tantangan tersebut agar dapat meningkatkan kualitas pariwisata daerah.

\section{References}

[1]Ramadhan, W. O. J., Sudirman, F. A., Saidin, S., \& Susilawaty, F. T. (2020). Promosi Kuliner Jepang Melalui Media Sosial Sebagai Bentuk Diplomasi Publik: Studi Facebook Kedutaan Besar Jepang di Indonesia. Jurnal Ilmu Komunikasi UHO: Jurnal Penelitian Kajian Ilmu Komunikasi dan Informasi, 5(1), 63-75.

[2]Sudirman, F. A., Sarma, W. O. D., \& Susilawaty, F. T. PROMOSI PARIWISATA MELALUI DIGITAL DIPLOMACY: UPAYA INTERNASIONALISASI PARIWISATA DAERAH. Jurnal Ilmu Komunikasi UHO: Jurnal Penelitian Kajian Ilmu Komunikasi dan Informasi, 5(3), 174-185. 